\title{
Vila União dos Operários, Canoas, RS: luta por moradia e habitabilidade (1980-2014)
}

\author{
"Vila União dos Operários, Canoas, RS": fight for housing and \\ habitability (1980-2014)
}

\author{
Enviado em: 29/03/2018 \\ Aceito em: 28/07/2018 \\ Ivo Fiorotti ${ }^{1}$ \\ Cleusa Maria Graebin ${ }^{2}$ \\ Lucas Graeff ${ }^{3}$
}

\begin{abstract}
Resumo:
O estudo tem como objeto as lutas por moradia e melhores condições de habitabilidade ocorridas em Canoas, RS, entre 1980 e 2014. Centra a atenção no processo histórico da ocupação de terreno pertencente a um Jóquei Clube, localizado no Bairro Mathias Velho, dando origem à Vila União dos Operários. Foram 34 anos de luta, por parte dos moradores, que passaram de ocupantes a proprietários de seus lotes. Para dar conta da pesquisa, foram utilizadas fontes escritas e orais, estas produzidas a partir de grupos focais. Teoricamente, o trabalho fundamenta-se em pressupostos da História Social e História Urbana e na Sociologia e Antropologia urbanas, dialogando por meio do conceito de memória social. Constatou-se, a formação de um movimento social de luta que culminou com a posse legal de um território urbano, a partilha dos lotes e a presença de sociabilidade na construção de equipamentos urbanos e de moradias.
\end{abstract}

Palavras-chave:Vila União dos Operários; Luta por moradia e habitabilidade; Movimento social.

\section{Abstract: \\ This work has as object of study the struggles for housing and better living conditions in "Canoas, RS", between the years of 1980 and 2014. It focuses attention on the historical process of the occupation of land belonging to a Jockey Club, located in}

\footnotetext{
${ }^{1}$ Mestre em Memória Social e Bens Culturais (Unilasalle).

2 Doutora em História (Unisinos), professora e Coordenadora Adjunta do PPG em Memória Social e Bens Culturais (Unilasalle).

${ }^{3}$ Doutor em Etnologia e Sociologia Comparada pela Université Rene Descartes (Paris V, Sorbonne), professor e Coordenador do PPG em Memória Social e Bens Culturais (Unilasalle).
} 
the "Mathias Velho" district, that later became the "Vila União dos Operários". The residents struggled for 34 years to pass from occupants to owners of their lots. To conduct the research, written and oral sources produced from focal groups were used. Theoretically, the work is based on premises of Social History and Urban History, and in Urban Sociology and Anthropology, dialoguing through the concept of social memory. We found the formation of a social movement of struggle that culminated in the legal possession of an urban territory, the sharing of lots and the presence of sociability in the construction of urban equipments and houses.

Keywords: "Vila União dos Operários"; Fight for housing and habitability; Social Movement.

\section{Considerações iniciais}

Este trabalho investiga o processo histórico do movimento social de luta pelo acesso à moradia e por melhores condições de habitabilidade ocorrido na cidade de Canoas/RS entre 1980 e 2014. Nesse período, o movimento iniciou com a ocupação do espaço do antigo Jóquei Clube de Canoas, deu origem à Vila União dos Operários, no Bairro Mathias Velho, e culminou na regularização fundiária em meados de 2014. Trata-se de um evento ímpar na história das lutas por moradia no Brasil, abrangendo três décadas e meia de lutas e ações que encaminharam a transição da condição de ocupante à condição de cidadão, enquanto proprietário do seu lote com sua moradia.

Em Canoas/RS, o fenômeno de urbanização tem origem nas décadas de 1940 e 1950, no contexto do crescimento da industrialização e expansão da busca de moradias de baixo custo, por contingentes de população oriundos de movimentos de migração ${ }^{4} \mathrm{e}$ imigração ${ }^{5}$ para Porto Alegre, capital do Rio Grande do Sul e cidades vizinhas a essa, as quais estudiosos denominam como cidades-operárias (GOHN, 1995; WEBER, 2004). No Município, foram urbanizadores particulares que organizaram os loteamentos de terrenos, a grande maioria em espaços degradados, desprovidos de infraestrutura (sem redes de esgoto pluvial e cloacal, água potável, iluminação, pavimentação) e frequentemente localizados em várzeas alagáveis dos Rios Gravataí e dos Sinos. Entre 1950 a 1960, o crescimento populacional do Município foi de 390\% (FEEE, 1981).

\footnotetext{
${ }^{4}$ Originários de inúmeros locais do Brasil, notadamente os do Rio Grande do Sul.

5 Vindos da Alemanha, Itália, Polônia, Ucrânia, Portugal, nos momentos pré, durante e pós Segunda Guerra Mundial.
} 
Na visão de Sezefredo Azambuja Vieira, Prefeito de 1956 a 1959, Canoas foi "uma cidade que cresceu às avessas" (citado por VIEGAS, 2011, p. 136). É nesse contexto de crescimento "às avessas" que se inscreve o processo histórico de luta por moradia e habitabilidade apresentado neste artigo. Como foi possível que um grupo de indivíduos e famílias recém-chegados das lidas da roça para a cidade ou ainda, fugindo do aluguel na própria zona urbana, tenham se organizado para agir de maneira concertada na conquista de um espaço de vida e habitação? Quais as circunstâncias possibilitaram a conquista judicial da posse da terra? Como a geração atual de moradores relembra as origens de luta e ocupação da Vila onde moram? E, sobretudo: Como essas lembranças de um passado de conquistas mobilizam - ou não - o conjunto de moradores no sentido de obtenção de novas melhorias coletivas para suas vidas?

Para dar conta dessas questões, os autores e a autora apoiaram-se em uma pesquisa realizada entre 2012 e 2014 no Programa de Pós-Graduação em Memória Social e Bens Culturais, da Universidade La Salle, e em um conjunto consolidado de pesquisas realizados no âmbito do Grupo de Pesquisa Memória, Cultura e Identidade (CNPq). Em linhas gerais, todas essas pesquisas são históricas, mas de caráter interdisciplinar; e, mais especificamente, os pesquisadores e pesquisadoras dialogam por meio do conceito de memória social que, como sugere Jô Gondar (2016), é transdisciplinar, relaciona-se invariavelmente com o esquecimento, não se confunde com os conceitos de identidade ou representação e, sobretudo, é objeto de disputas e de apropriações políticas.

O presente artigo situa-se no campo da História Social, em particular da História Urbana. Fundamenta-se, também, em autores e reflexões dos campos da Sociologia e da Antropologia Urbanas. O objeto da pesquisa é tratado por meio de fontes escritas e orais e das próprias experiências dos autores e autora, que vivem em Canoas/RS e vem estudando a sua formação sócio-histórica e cultural há vários anos. Além disso, optou-se pelo uso de grupos focaiscomo técnica de pesquisa qualitativa. Segundo Minayo (2012), os grupos focais são constituídos de seis a doze interlocutores e animados por um ou dois pesquisadores, que conduzem a conversa enfocando determinados temas, promovendo a participação de todos, inibindo os monopolizadores e aprofundando a discussão. No caso desta pesquisa, foram formados três grupos com sete a oito participantes. Cada um dos grupos foi organizado observando tanto a questão da periodização do movimento social como a diversidade de funções de seus atores sociais: o primeiro, com moradores que foram atores sociais no período da resistência; o segundo, com moradoras que foram atores sociais na fase inicial da expansão da ocupação e nas primeiras lutas pelas condições de 
habitabilidade; o terceiro, com moradores que chegaram a partir da década de noventa ou nasceram na comunidade, sendo atores sociais com funções nas lutas pela ampliação das condições de habitabilidade.

O texto está organizado em duas seções. Na primeira, apresenta-se uma breve contextualização das dinâmicas ocupacionais que delimitam o território onde, atualmente, encontra-se a Vila União dos Operários. Em seguida, são apresentadas algumas memórias fortes (CANDAU, 2011) dos sujeitos de pesquisa, bem como uma síntese geral dos achados que foram produzidos por meio dos grupos focais. O objetivo maior é apresentar o processo histórico dessa mobilização - que pode ser considerada ímpar em virtude da conquista da posse - por meio de diferentes perspectivas e fontes de pesquisa. Ao mesmo tempo, os autores e a autora deste artigo trabalham com a hipótese de que a memória social da mobilização enquadra o sentimento de identidade coletiva que a comunidade cultiva até os dias de hoje.

\section{Contextualização das dinâmicas ocupacionais que deram origem à Vila União dos Operários, em Canoas/RS}

Entre as questões urbanas enfrentadas pela cidade de Canoas/RS em seu rápido processo de urbanização, a criação de loteamentos irregulares e ou clandestinos e os regulares ocupa uma posição de destaque. Em muitos casos, são oriundas de ocupações de terrenos de propriedade privada ou pública, consolidando-se em meio a escassez de equipamentos públicos e infraestrutura.

No contexto nacional dos anos 1970, marcado pelo crescimento econômico acelerado que oportunizou a migração de grande número de pessoas tanto do campo para a cidade, como de cidades pequenas para regiões metropolitanas, Canoas/RS teve o que um ex-Prefeito (Carlos L. Giacomazzi) chamou de "[...] migração violenta do homem do campo para os grandes centros" (citado porPENNA et al., 2000, p. 80). Ainda segundo depoimento desse gestor, a situação dos moradores era de total precariedade. Viviam

\footnotetext{
[...] jogado[s] na água, sem ruas, sem transporte. Ao sair de casa era lodo até o joelho. Era um verdadeiro inferno! Uma coisa de matar, de quebrar o coração da gente. Era tudo loteado, tudo tomado, ranchos em toda a parte... Era um negócio que assustava (idem, p. 80).
}

O crescimento econômico foi partilhado de forma desigual fruto das transformações no modo de produção capitalista do período que produziu desemprego e precarizou as 
relações de trabalho. Esta situação também gerou um crescimento urbano desordenado que jogou imensas maiorias de migrantes a morarem em áreas precárias e em condições de habitação desumanas, como o que foi vivenciado em Canoas/RS. ${ }^{6}$

No caso particular da área onde, hoje, encontra-se a Vila União dos Operários, um marco histórico notável é a sua relação com a antiga loteadora São Carlos, fundada em 1951 pelos herdeiros de Saturnino Brito Velho ${ }^{7}$. A autorização legal definitiva da Prefeitura de Canoas para venda de lotes ocorreu a partir de 1954. Nos planos, além de oferecerem possibilidade de lar próprio aos moradores recém-chegantes, estava a construção de um hipódromo (PENNA et al., 2000).

Em meados da década de 1970, o loteamento da Vila São Carlos passou a denominar-se Bairro Mathias Velho (Lei 1.662/75), compreendendo a maior parte das terras do quadrante noroeste de Canoas. Interessante notar que as ruas transversais com nomes de cidades sul-rio-grandenses e de capitais de estados brasileiros demarcam a procedência dos migrantes e apontam para possível manutenção de identificação de grupos de pertencimento, pelo menos, quanto a sua origem.

A fundação do "Jóquei Clube de Canoas" ocorreu em 16 de setembro de 1952, reunindo personalidades da elite da região metropolitana de Porto Alegre. As obras de construção iniciaram somente em 1954 e se estenderam por mais de quatro anos (HISTÓRIA, 2003). Foi inaugurado em fins de 1958, tendo estrutura de cancha de corrida, restaurante, arquibancada e baias de cavalos, sendo o primeiro Hipódromo sul-riograndense com iluminação noturna (HISTÓRIA, 2004). Passou a realizar corridas em vários dias da semana com ampla divulgação nos jornais da capital e, a partir de 1962, com atividades noturnas às quintas-feiras (HISTÓRIA, 2005, p. 188-189). Para oportunizar proximidade residencial aos seus funcionários e para obter dividendos, o Jóquei Clube de

\footnotetext{
${ }^{6}$ Estudando o contexto do Rio Grande do Sul no período, Brum (1982) constata que a década de setenta conheceu o maior deslocamento migratório do campo para a cidade, fruto de transformações ocorridas na estrutura produtiva primária que inviabilizaram a produção da pequena propriedade beneficiaram a modernização e mecanização da produção agrícola, acrescida pela construção das grandes barragens que expulsaram significativo contingente de famílias que viviam em pequenas propriedades e minifúndios.

${ }^{7}$ Saturnino Brito Velho, nascido em Mostardas em 29 de novembro de 1850, foi tropeiro e Coronel da Guarda Nacional. Em 1882, adquiriu porção de terras na parte oeste da cidade (atuais bairros São Luís, Mathias Velho e Harmonia) dos herdeiros da Fazenda Gravataí, da antiga Sesmaria do tropeiro lagunista e posterior major do Exército Português, Francisco Pinto Bandeira. Este demarcou porção de terras ao norte do Rio Gravataí em 1733, obtendo Carta desta Sesmaria em 27 de maio de 1740. Com sua morte, a fazenda foi deixada para seu filho Rafael Pinto Bandeira. Posteriormente, Rafaela Pinto Bandeira, a Brigadeira, herdou a fazenda, casando-se com Vicente Ferrer da Silva Freira, família da qual Saturnino adquiriu as terras. Cf. FARIA, Otavio Augusto de. Diccionario Geográphico Histórico e Estatístico do Estado do Rio Grande do Sul. Porto Alegre: Ed. Globo, 1914, p.8.
} 
Canoas decidiu lotear terrenos junto à área do seu entorno nas Ruas Livramento, Florianópolis e São Sepé, perfazendo 8 hectares.

Ao longo da década de 1960, ocorreram diversas enchentes na cidade, com grandes prejuízos para o Bairro Mathias Velho. Os administradores do Jóquei tiveram inúmeras perdas, o que acarretou dívidas que encaminharam o encerramento de suas atividades no final da década de 1970. Entre os seus credores estava a Companhia Estadual de Energia Elétrica (CEEE) que ficou com a parte não loteada do espaço em troca das dívidas e, em um leilão público, três cidadãos arremataram os 42 hectares, registrando-os ${ }^{8}$ no Cartório de Registro de Imóveis de Canoas em 1973. Foram eles: Lauro Lindemann, Nelson Covolo e Paulo Neujahr Blauth e suas respectivas esposas. Foi esse o espaço ocupado por migrantes e, em 1982, durante um conflito judicial com posseiros, os proprietários constituíram a urbanizadora "Negócios e Empreendimentos Imobiliários (NELPA)", que passou a responder judicialmente pela tentativa de reintegração de posse.

Em Canoas, no interior desta realidade, desencadeou-se um processo animado por educadores populares ligados à Teologia da Libertação ${ }^{9}$, em especial os irmãos Antônio Cechin ${ }^{10}$ e Matilde Cechin que, a partir de famílias de rezadores e do trabalho com as mulheres (mães) organizaram o movimento ocupacional de duas vilas, a Santo Operário e a União dos Operários. Investigações já realizadas por Fiorotti (1985) e Machado (2012) detalham elementos importantes que dinamizaram essa luta pelo acesso à moradia e às condições de habitabilidade nas vilas citadas, as duas maiores ocupações de áreas particulares ocorridas no início dos anos 1980 em toda a Região Metropolitana de Porto Alegre $^{11}$

São vários os estudos que se dedicam à compreensão de como ocorreu a chamada revolução no cotidiano urbano em que emergiram esses movimentos sociais com seus atores coletivos (SADER, 1988; SHERER-WARREN \& KRISCKE, 1987 e 1989). As exaustivas investigações de Gohn (1991, 1995, 1997, 2003 e 2005) além de compreender a novidade do processo de construção da cidadania dos brasileiros a partir das lutas coletivas e sua organização nos movimentos sociais, insere uma profunda investigação no campo das

\footnotetext{
${ }^{8}$ Matrícula registrada no Cartório de Registro de Imóveis de Canoas, com área de cerca de 43 hectares, inscrita no Livro3-AD, fls.76, n. -49.089.

9 "A Teologia da Libertação nasce das CEBs [...] é a reflexão da fé dos pobres, dentro de suas lutas por libertação, que produz as bases da Teologia da Libertação [...]. A Teologia da Libertação é um novo modo ou método de ser fazer teologia. Ou um novo olhar sobre as fontes bíblicas da revelação cristã e a tradição da Igreja. Esse modo, esse método e esse olhar têm um centro ou lugar social: os pobres". Cf. BETTO, Frei. Catecismo Popular. São Paulo: Ática, 1991, p. 172.

${ }^{10}$ Irmão Marista, fundador da Comissão Pastoral da Terra do Rio Grande do Sul (CPT-RS).

${ }^{11} \mathrm{~A}$ Região Metropolitana de Porto Alegre (RMPA) foi instituída formalmente através da Lei Complementar Federal 14 de 08/06/1973, integrando 14 municípios, entre eles, o de Canoas. Atualmente integra 34 municípios.
} 
lutas pela moradia. Destaca que as ações coletivas de luta popular no Brasil, nos anos das décadas de setenta e oitenta do século $X X$, tiveram vários impulsos, sendo o principal, a "crença no poder quase que mágico da participação popular" (GOHN, 1995, p. 203). Portanto, existe um nexo profundo entre a luta coletiva por moradia e condições de habitabilidade com participação social e construção da cidadania. A constituição de sujeitos coletivos que organizam lutas como "[...] uma coletividade onde se elabora uma identidade e se organizam práticas através das quais seus membros pretendem defender seus interesses e expressar suas vontades" (SADER, 1988, p.55).

Em 2009, a Associação de Moradores da Vila União dos Operários (AMVUO) liderou uma ampla mobilização na busca de recursos públicos tendo em vistas a regularização fundiária, com a formalização do loteamento e a escrituração dos lotes. Após uma disputa com várias demandas dos moradores do Bairro Mathias Velho, os recursos públicos foram conquistados por meio do Orçamento Participativo $(\mathrm{OP})^{12}$, forma de cogestão entre estado e sociedade civil na execução de programas públicos e projetos governamentais. O projeto do loteamento manteve integralmente o desenho urbanístico existente, conservando o traçado de ruas, a configuração dos lotes e a manutenção dos espaços públicos consolidados.

Os posseiros da Vila União dos Operários vão, ao longo do processo ocupacional, se constituindo como um ator social coletivo, com suas lideranças, seus assessores de apoio, formando redes e articulações. Em sua primeira fase, interessava ao ocupante encontrar e ter um lugar para morar, um terreno para fugir do aluguel e construir sua própria morada, mesmo em condições precárias. Aquele momento de luta pelo acesso à moradia caracteriza-se pela chegada de uma centena de famílias no território, mantendo-se ali entre 1980 e fins de 1983. As ações coletivas do movimento social, nessa fase, são de resistência na posse. Ao ser garantida a posse pela via judicial, a força social deste movimento passa a organizar a ocupação de todo o espaço. A ocupação planejada ocorreu ao largo da ação do poder público. Foi uma ação conjugada da assessoria e das lideranças com a participação ativa da base social, o conjunto dos moradores, enfrentando uma luta social violenta no local e no campo judicial com os proprietários.

Mas como todo esse contexto histórico se articula - ou é reconstruído - do ponto de vista dos indivíduos, grupos e famílias que lutaram e conquistaram a posse da terra, tornando-se fundadores da Vila União dos Operários? Como, hoje, o passado é trabalhado

12 O Orçamento Participativo (OP) é uma ferramenta de participação cidadã que viabiliza demandas coletivas. Adotado pela administração municipal de Canoas, compunha, com mais 12 ferramentas, o Sistema de Participação Cidadã, visando a radicalização da democracia. Cf. JORGE, Jairo. Radicalizar a Democracia. Porto Alegre:Tomo Editoria, 2014. 
pela memória em grupos focais, isto é, pela intermediação de pesquisadores interessados nas dimensões históricas, sociais e culturais de uma luta emblemática pela moradia e habitabilidade em Canoas/RS? Na sequência deste artigo, apresentam-se narrativas por meio das transcrições desse trabalho de memória que materializa e reinventa a duração social desses mesmos indivíduos, grupos e famílias - e, é claro, da própria ideia de "identidade" da Vila União dos Operários.

\section{Da conquista à partilha da terra ao habitar coletivo: entre eventos e sentimentos ${ }^{13}$}

Antes de nós, "aqui era o Prado", sentencia Jandira (2014), nome popular do Jóquei Clube. É Dejair (2014) quem lembra: "como se diz, um jóquei”. Juca (José Antônio da Conceição) (2014) faz uma descrição detalhada: era "de areia, tudo iluminado e nas quintasfeiras começava às oito da noite e ia até a meia-noite com as carreiras, tudo que dá num prado aquilo, tudo tinha aqui”. Na década de setenta, com o Jóquei demolido, Edelmiro (2014) relata que carreiras eram promovidas nas duas canchas retas ali "onde hoje se localizam as ruas Sino da União e Romeiros". Judite (2014) lembra que quando chegou era "um campo de criar cavalo, boi". Juvila (2014) recorda que os "valos de raias que tinham ali eram nosso refúgio [...] dos cavalos passarem por cima da gente". Jair não conheceu, mas mostra aqui uma "memória por tabela" (POLLAK, 1992), ao relatar que ouviu falar do antigo prado, das corridas de cavalos.

Dejair, Edelmiro e Juvila dão vida aos eventos e acontecimentos que permeiam a memória coletiva da comunidade. São depoimentos que evocam questões de origem: em que condições e como chegam estes moradores à atual Vila União dos Operários? Por que migraram? Como eram suas vidas antes do que, hoje, reconhecem como morada?

Juvila diz que pagava aluguel e fez uma casinha com duas peças. Fechou um pedaço do terreno para plantio, perto da atual Igreja Divino Mestre. Lembra que chegou em 1979 e oito meses após perdeu o marido, ficando com as meninas. A data que precisa a chegada foi a da morte do marido, referenciada na idade das filhas: "a mais velha tinha $16 \mathrm{e}$ a Iza tinha seis". Com a morte do marido, o vizinho Ihe cortou o fornecimento da luz elétrica, tendo como justificativa estar vendendo a casa, mas imagina não ser a verdade. Através das Irmãs do Colégio Espírito Santo em que trabalhava, foi auxiliada por um diretor da CEEE (Companhia Estadual de Energia Elétrica), o qual a orientou e a ajudou a colocar um poste

\footnotetext{
${ }^{13}$ Para dar fruição à leitura, foi colocado o ano da Entrevista Grupo Focal junto aos nomes dos entrevistados, na ordem em que aparecem no texto pela primeira vez.
} 
próprio. Recorda da afirmação do diretor da CEEE: "[...] quando eu ligar ninguém mais desliga". É muita grata ao Luiz da CEEE que lhe prestou esta ajuda.

De Sobradinho, Maria Gessi (2014) veio em 1981 com o marido e quatro filhos. O marido veio antes com a missão de adquirir um local próprio, pois não queriam pagar aluguel. Maria Gessi ficou na lida da roça, fazendo a colheita. Dois meses depois, o marido chega com o caminhão e trazem a mudança para Canoas/RS. O caminhão entra na área por meio de um precário pontilhão sobre um valo junto à Rua Florianópolis. Quando chega ao local, chora e briga com o marido pela precariedade da residência. Este lhe diz: "É o que eu pude comprar". Continua narrando que a casinha, embora precária, foi a que abrigou a família, era dela: "essas quatro telhas aqui são minhas".

Judite conta que pagava aluguel e com as invasões, não lembra o ano, veio para a Rua Florianópolis, próximo à casa do pai, onde foi celebrada a primeira missa. Diz que ficou uma semana com os cinco filhos bem pequeninos embaixo de uma lona. O marido conseguiu umas madeirinhas na obra em que trabalhava como carpinteiro e construiu uma casinha. Enquanto contava, Juvila descreveu a casa, com gestos largos entre os dedos: "com frestas assim... e buracos". Por ocasião da medição dos terrenos, no local onde reside atualmente, fez com o marido uma horta e plantaram feijão carioquinha: "E nós colhemos bastante feijão que ficamos comendo por bastante tempo. Milho verde nós plantamos e colhemos. Vimos que a terra era boa. Daí era só plantar". Neste momento todos recordam e cantam a música que o Irmão Antônio Cechin Ihes havia ensinado: "A terra é de todos, disse Deus a Adão, toma e cultiva tira dela o teu pão"14. Foi um momentode expressão de uma memória forte!

Adegildo (2014) confirma fala da Judite: a terra é boa e produtiva. Ele conta que havia se instalado próximo à Rua Florianópolis, onde hoje é a Rua Sino da União. Antes, pagava aluguel e trabalhava como carpinteiro. O salário era "bem baixo e humilde". A decisão de vir para a ocupação visava um futuro melhor para a família que incluía sustento e acesso à educação dos filhos: "Era conseguir um lugarzinho para morar e botar as crianças em um colégio [...] para futuramente termos as crianças formadas, né, e ficar melhor".

A memória é trabalhada por Juvila, Maria Gessi, Judite e Adegildo. Ela trata do "acontecimento": a chegada ao território que, hoje, Ihes pertence. Nesse trabalho de memória, mais que uma precisão cronológica, as lembranças relacionam-se a eventos e

14 PEREIRA, Odvaldo Nascimento. Vida do Migrante (11/12/1980). In: Poesia Popular.Anexo do Boletim da gente, no 13, Janeiro/Fevereiro. CEDIV-Centro de Documentação da Igreja de Vitória, [s/d], p. 10. Disponível em $<$ http://www.cpvsp.org.br/upload/periodicos/pdf/PPOEPES010000005.pdf>. Acesso em 12 de agosto de 2017. 
acontecimentos da intimidade, isto é, da vida pessoal, familiar ou profissional. É nesse sentido que são representações factuais indicativas de formação de memórias fortes (CANDAU, 2011). Elas reverberam afetivamente o acontecimento, enquadrando-se no tempo e no espaço, como causa ou consequência, como índices dos quadros sociais e afetivos da memória coletiva de um grupo (HALBWACHS, 2006).

Com o casal Juca (José Antônio da Conceição) e Lair (2014), um novo quadro de rememoração se apresenta. Um quadro rico, detalhado, pleno de sentidos para seus narradores. Em particular, Juca, que rememorou lembranças de sua infância convivendo com o hipódromo, indica com gestos a ocorrência de cenas, bem como a localização atual de espaços e equipamentos do período do Jóquei:

\begin{abstract}
[...] eu me criei aqui. 56 anos tá fazendo em setembro que eu nasci e me criei na Rua Sarandi. Eu sou daqui do tempo que era prado, isso aqui era coisa muito linda [...] Nas quintas-feiras, começava às oito da noite e ia até a meia-noite com as carreiras, tudo que dá num prado aquilo, tudo tinha aqui, aonde é a igreja, aqui era arquibancada [...] embaixo tudo era pavilhão e depois na frente onde é o posto de saúde era um restaurante [...] e lá que era as árvores. Do lado de lá era dos arremates, depois atrás onde era as caixas d'água era as cocheiras, que nós trabalhava. Nós era guri, nós trabalhava limpando as cocheira [...] gente descia daqueles carros [...] era só burguês [...] aqueles carro antigo, porque na Mathias [...] tudo era chão, não tinha luz, não tinha água. Só tinha no prado, aqui, porque vinha por aqui pela Harmonia, vinha luz pra cá [...] já era casado, e morava na Berto Círio [...] a Associação do Jóquei Clube de Canoas, cedeu pros funcionário os terreno ali. Então, muita gente abandonou aquilo, não quis né, daí a irmã comprou [...] um dia eu vim passear na casa dela e fiquei olhando pra dentro do prado. Ali, né? Nos fundo da casa dela. Fiquei olhando assim, 'Bah que vontade de meter uma casa aqui.'; 'Ah por que tu não metes?'; 'Ah eu vou fazer então'. Aí eu peguei uma carroça, uma bicicleta, e 500 cruzeiros [...] negociei com um cara, dei a carroça, eu dei a bicicleta e aquele dinheiro que eu tinha por uma casinha. A casa era tão grande, mas tão grande, que nós tiramos o telhado que era de telha francesa, metemos uns paus embaixo assim e, entre quatro, nós pegamos a casa, levantamos e o caminhão entrou de ré embaixo [...] ai nós entramos lá pela raia do prado eu tenho a foto da raia do prado [...] Tinha um arreião assim e cheguemos lá, levantemos aquela casa, o caminhão saiu debaixo, larguemos aquela casinha. Aí chegava visita lá em casa, nós saíamos pra rua e a visita entrava pra dentro de casa por que não podia ficar dentro de casa (JUCA, 2014).
\end{abstract}

Nas lembranças de Lair, as violências dão teor aos eventos: "[...] a gente lutou, a gente brigou, a gente apanhou, [...] a gente não dormia de noite, correndo atrás dos capangas dos donos daqui, que queriam impedir as pessoas de colocar as casas aqui". Curiosamente, nas falas de Juvila, a violência não aparece. Tudo se passa como se a relação com os proprietários fosse de aproximação e cordialidade - ao menos no início. Lembra do argumento que seu falecido marido usou para convencer o Air Bergental a deixálos ficar: "Olha, já morei 12 anos num terreno que não era meu e nós saímos. Por isso é que nós estamos aqui. Mas na hora que vocês precisarem, nós saímos". Na narrativa de Juvila, 
Bergental não parece ser quem patrocinou as ações violentas no território. Para ela, foi o número de pessoas instaladas no terreno que mudou tudo: "começou a chegar gente e mais gente e eles começaram a ficar violentos".

Adegildo, por sua vez, chega a lembrar dos gritos do Bergental: "Isso é uma turma de preguiçoso que me invadiram a propriedade!". Em seguida, relata: "foi uma batalha muito forte e tempos muitos difíceis'. Os capangas derrubavam as casas com caçamba e retroescavadeira no momento em que o marido estava no trabalho ou a esposa no colégio para buscar as crianças. Ao retornar, restava ao morador "[...] fazer de novo a casinha para evitar que molhasse alguma coisa que tinha dentro".

Com o avanço das falas durante o grupo focal, Juvila chega à conclusão: "procuro não lembrar para viver mais". Jandira concorda: "lembrar do passado é sofrer duas vezes". A memória, com efeito, não é só forjada de bons sentimentos e lembranças. Dor e sofrimento também conformam quadros e, conforme o caso, podem reconfigurar ou mesmo bloquear o passado. Tal dimensão memorial, aliás, precisa se desdobrar para além da indulgência do pesquisador para com seu sujeito de pesquisa ou interlocutor, para além da figura de "vítima" (GENSBURGER E LEFRANC, 2017). Não se trata de proteger ou explorar a dor e o sofrimento, mas de pensar o trabalho de memória nessa "situação paradoxal, na qual, de um lado, parece haver o triunfo do esquecimento, recobrindo com um véu de obscuridade nuanças das ações humanas, e, de outro, o surgimento de mobilizações combatentes [...]" (FARIAS E PINTO, 2016, p. 178).

As lembranças da chegada e das ações de resistência também revelam memórias fortes de ações individuais das famílias - como é o caso da temática da ajuda mútua entre vizinhos. No início da resistência na posse "um ajudava o outro", conta a Jandira. Mas como ocorriam as ações de ajuda solidária? Juvila fala com orgulho: "Eu tinha um pé de cabra e um pedaço de trilho de trem. Batia naquilo lá e era melhor que o sino. Acordava todo mundo. Era assim". E todos riem! Judite fala mais: "Qualquer coisa um vizinho corria na casa do outro". Jandira faz uma comparação do que viveram no passado e do que ocorre nos dias atuais: "É que naquela época o pessoal era mais unido. Éramos bem mais unidos" Adegildo traz uma fala que revela a força social na resistência: "Nós estávamos mais organizados, eles estavam em poucos".

Outra memória forte relacionada à chegada e à resistência refere-se ao sino, símbolo da força coletiva. Ainda que haja uma disputa em relação a suas origens. Judite diz: "foi o Orlando"; Gessi pergunta-se: "Não foi o Ivo[Ivo Fiorotti]?"; “O próprio Bergental tentou roubar o sino, mas não conseguiu", dizem Judite e Dejair. A sua presença no alto de uma cruz de 
eucalipto e suas batidas convocavam os moradores à época, como uma força coletiva de resistência e, hoje, como uma força coletiva de lembrança. É como se o sino representasse a resistência coletiva, a duração social do grupo.

De par com o sino, a capela Divino Mestre é outro símbolo de coesão social. Nela, organizava-se o Clube de Mães, uma ação coletiva articulando fé e vida, leitura da Bíblia e ações concretas voltadas à superação de necessidades (FIOROTTI, 1987). O mutirão das mães foi a primeira ação comunitária que deu resposta às necessidades ligadas às condições de habitabilidade, particularmente para enfrentar o frio e a fome. Constituiu fator de coesão social dos ocupantes, auxiliando na resistência coletiva quanto à posse da terra. As Frentes de Trabalho (FETs), no período da ampliação da ocupação para todo o território, fortaleceu esta ação coletiva. Inicialmente, as ações da Igreja Divino Mestre (capela) e da Associação de Moradores da Vila União dos Operários (AMVUO) confundiam-se por ocuparem o mesmo espaço. Gradativamente, a AMVUO passa a ser a força dirigente da ampliação das condições de habitabilidade deste movimento ocupacional, enquanto as ações da lgreja se mantêm relacionadas à formação e celebração espirituais.

No debate da escolha do protetor da capela, conta-se que o nome Divino Mestre foi aceito pela pluralidade das expressões religiosas ali presentes. Nas palavras de Juvila: "quem escolheu foi o Irmão Antônio que daí ele explicou para nós: 'olha vai ser Divino Mestre que é o santo de todas as religiões. Assim ele acolhe todos. [...] Então Divino Mestre, que ele é o divino mestre de todas as religiões" [...] coisa mais boa, cada um com sua religião".

De certa forma, foi em torno da Capela Divino Mestre que se articularam as ações pioneiras visando o aprimoramento das condições de habitabilidade na Vila União dos Operários. Desde ali, as mulheres em mutirão empreendiam ações de proteção contra o frio. Faziam acolchoados, agasalhos e roupas. Reaproveitavam os tecidos. Superavam a fome, com a produção de pães nos fornos comunitários. É de Iracema as lembranças que detalham a ação destes mutirões:

\footnotetext{
No forno comunitário [...]. Íamos em mutirão pedir farinha nos moinhos lá pra Porto Alegre [...]. Se conseguia farinha e voltava e se partilhava ... a farinha elas faziam o pão, onde elas tinham pão em casa pra dar alimento pras crianças. [...] mulheres que se reuniam semanalmente para fazer acolchoado de roupa velha, faziam tudo que era necessário, roupinha para criança, e partilhava, não era pra uma. Faziam pra quem precisava mais [...] Primeiro de começar a trabalhar no clube de mães, era a Bíblia. Lá se refletia e depois se trabalhava. Acho que muito acolchoado foi feito, tinha doações também das Irmãs. [...] os Freis também ajudavam muito, para buscar os retalhos e roupas (IRACEMA, 2014).
} 
As ações solidárias dos mutirões das mães foram ampliadas frente às necessidades do crescente contingente de pessoas no território e em virtude de um período de agravamento das condições de emprego. Dejair sentencia: "Época de vacas magras". Juvila, que na chegada trabalhava em uma escola, diz: "uma época que eu estava desempregada, geralmente estavam todos desempregados, não tinha serviço para ninguém". Recordam que as Frentes Emergenciais de Trabalho (FETs) foram uma conquista junto à prefeitura. Essas, estavam presentes em outras vilas, lembra Dejair. Juvila, uma das coordenadoras, recorda um slogan dessa luta: "Nós estamos morrendo de fome, queremos emprego". O programa público das FETs oportunizava trabalho comunitário e possibilidade de acessar o alimento.

As Frentes Emergenciais de Trabalho tiveram papel central na estruturação do loteamento e no fortalecimento das ações comunitárias - em particular, nos trabalhos dos mutirões das mães. Lair detalha com gestos como confeccionava os acolchoados: "Roupa velha. Colocava o tecido no chão, ia ajeitando as roupas e passava um cordão no meio assim atravessado. Eu tenho um guardado lá em casa". Iracema acrescenta outras ações exercidas pelas mulheres nas FETs: "era os clubes de mães, era o mutirão da comida, era o sopão que se fazia na Vila".

Uma memória forte incontornável para os sujeitos de pesquisa é a audiência da vitória judicial da posse. Segundo as fontes históricas, a audiência ocorreu junto ao $1^{\circ}$ Grupo de Câmaras Cíveis do Tribunal de Alçada do Poder Judiciário do Rio Grande do Sul, em 18/11/1983. Na ocasião, os juízes julgaram a permanência dos posseiros em suas moradias no território da Vila União dos Operários. Mas, para os entrevistados, o que vem à tona não são os detalhes da decisão, mas a efervescência de sentimentos que essa lembrança provoca em todos. Juvila sintetiza tal efervescência. Segundo ela, havia um sentimento de derrota entre todos: "É hoje que nós perdemos", diziam. Foi uma surpresa, portanto, quanto o juiz declarou, segundo ela: "Está chegando o Natal, como é que a gente vai botar essas pessoas para a rua? Eu dou meu voto a favor". Juvila continua narrando: "[...] aí ele ficou olhando, como quem diz assim: Eles sobreviveram".

Aquele momento decidiu o destino dos moradores: prosseguir com suas moradias no território ao invés de tomar outros rumos. Na lembrança de Juvila: "Quinze dias, antes do Natal nós tínhamos que sair". Na recordação de Adegildo, "por que se ele dissesse que a desocupação era imediata, né, não tínhamos a quem recorrer". As expressões "eles sobreviveram", "nós tínhamos que sair" e "não tínhamos a quem recorrer" revelam lembranças da abrangência coletiva dessa decisão, ou seja, decidia definitivamente o rumo de todas as famílias pela permanência ou não na área. 
Maria Adélia (2014), Maria Gessi e Jandira também narraram suas lembranças e sentimentos em torno da decisão pela posse. Maria Gessi conta: "Eu lembro que a gente entrou, e sentou ali, ninguém conversava. Era só escutando. O coração estava batendo forte, mas a cabeça estava lá em cima. Acho que eles ficaram meio com pena né, por que a gente ganhou mais pelo silêncio que fizemos [...]. Não éramos baderneiros, como se diz, e a gente estava querendo o que a gente merecia. O clima de silêncio no ambiente também foi destacado por Jandira: "Era assim, se passar um mosquito pela gente, se ouvia, era um silêncio". Adélia, por sua vez, também recordou que estava em oração e, ampliando a impressão de tensão no dia da audiência, diz: "E lá, na hora da reunião estava todo empatado, né, metade, metade a nosso favor e metade contra. E daí então a decisão foi do juiz, que decidiu por nós ficarmos porque não tínhamos onde morar [...]. Tinha uns que era no lado do Bergental e outros ao nosso favor. Daí tava empatado, né. Daí o juiz que decidiu. [...] eu sei que daí um deles, no final que deu a força para nós".

Jandira evoca uma questão importante: "o que fazer com tanta terra?". Nesse momento, os colegas do grupo focal tentaram lembrar do número exato de beneficiados com a decisão. Judite fala que "cada um tinha as suas famílias e suas famílias são colocadas, né, e seus filhos nenhum paga aluguel". Quanto aos filhos terem sua casa e seu lote foi questão pacífica. Por outro lado, foi preciso pensar além disso: "Vocês vão fechar uma chácara para cada um? O que vocês vão fazer? Eu não lembro quem, sempre vinha alguém perguntar", disse Juvila. Ela repete diversas vezes que não lembra quem perguntava se iam fechar uma chácara para cada um, mas acaba revelando um indicativo externo que motivou a partilha da terra:

Que a gente tinha ganhado, mas também tinha que olhar os outros, porque tinha tanta gente que precisava. Dai veio a Romaria da Terra, divisão de terra, por isso que teve as romarias aqui, mas agora o restante, a finalidade, como é que começou a gente ali, eu já não sei. Mas foi a finalidade da romaria da terra, foi com o consentimento dos moradores, pra depois começar a dividir um pedacinho pra cada um (JUVILA, 2014).

A Romaria da Terra ${ }^{15}$ foi, efetivamente, algo emblemático para a grande decisão sobre a partilha da terra. Segundo Juvila, a Romaria da Terra veio com o consentimento dos moradores para depois dividir um pedacinho para cada um. Ora, pode-se interpretar que Juvila estaria relatando eventos de uma forma cronológica. Já se viu que o processo de

15 Romaria da Terra de 6/3/1984, Vila Santo Operário, Canoas, RS. Cerca de 40.000 Romeiros, tema Terra e trabalho para que todos tenham vida. QUADRO das Romarias da Terra Rio Grande do Sul. Disponível em $<$ http://www.arquidiocesedepassofundo.com.br/site/download/romaria da terra/Quadro Romarias da Terra RS .pdf>. Acesso em12 de setembro de 2017. 
rememoração não tem a cronologia dos acontecimentos como relevância. Este é um caso específico na ancoragem dos eventos na rememoração de Juvila, pois ela passa o sentido lógico que a Romaria da Terra está intimamente relacionadaàresoluçãoda decisão da partilha dos terrenos, que vem como consequência.

A Romaria da Terra é, enfim, outro evento fundamental, que ancora as memórias dos narradores à imagem do sino, da Capela, do Clube de Mães, das FETs e da decisão sobre a posse. A Romaria ocorre na esteira da vitória judicial da posse, fato inédito nas lutas pela terra no Brasil. E, sobretudo, cumpriu uma função social específica que incrementou a força dos posseiros, freando o avanço da força dos proprietários que permaneceu ativa, apesar da derrota judicial.

A dinâmica dos grupos focais articulou uma memória coletiva das ações, das lutas e mobilizações pela conquista da terra e melhoria das condições de habitabilidade de Vila Santo Operário, em Canoas/RS. Em síntese, os grupos indicaram que tudo começou sem início planejado, sem organização prévia, sendo uma ocupação iniciada por famílias em busca de um lugar para viver e habitar. Essas famílias iniciaram uma saga coletiva de ocupação e resistência para residir em um pedaço de chão. Desde então, criam-se dinâmicas geradoras de coesão para os grupos de moradores, seja na resistência na posse ou na ocupação de todo o território. De forma planejada, organizaram ações coletivas de superação das necessidades internas e de crescente conquista das condições de habitabilidade junto aos órgãos públicos, até culminarem com a legalização do loteamento.

Com o tempo e a vida em comum, passam de relações familiares para relações coletivas, que formaram um sentimento de identidade comunitária - os grupos mencionaram as regras próprias de funcionamento, a coordenação de ações comunitárias e a estruturação coletiva do loteamento. Gradualmente, os moradores e grupos deixaram de lidar individualmente com a construção de seus barracos e a infraestrutura mínima para a vida - a luz elétrica e a água potável, notadamente - e tornaram-se famílias, que encontraram solidariedade umas com as outras. Assim, houve trocas de materiais e de trabalho para construção de casas e equipamentos comuns, que colaboraram para o desenvolvimento das condições de habitabilidade de toda a comunidade.

Mas, é claro, nem tudo se resumiu à solidariedade. Ocorreram conflitos, internos e externos. Ainda que o trabalho de memória dos grupos tenha evitado percorrer a dor e o sofrimento, houve pequenas manifestações e relatos sobre as violências e desilusões, em particular no que se refere às ações de intimidação pré-posse legal da terra. A fundação da Associação de Moradores da Vila União dos Operários e do Grupo de Mães não deixa de 
ser uma resposta a essas dores e sofrimentos. Quando o toque do sino passou a ser a principal forma de convocação coletiva para resistirem a todas as formas de intimidação e violência, fortaleceram-se as convicções de fé e os laços comunitários, por meio de reuniões, momentos de reza inter-religiosa, cantos, leitura da Bíblia e celebrações.

Ações conjugadas entre os apoiadores externos e os atores locais permitiram um processo de articulação mais ampla com outras vilas da cidade, emergindo como uma força social comunitária reconhecida na cidade. Essa força comunitária teve reforço com a fundação da União das Associações de Moradores de Canoas. Neste espaço mais amplo, demandas comuns foram viabilizadas. Dentre outras, a situação de carestia e desemprego formatou uma ampla articulação de desempregados em manifestações públicas, resultando na conquista das Frentes Emergenciais de Trabalho. Do ponto de vista da política de trabalho e emprego, um paliativo. No entanto, para os moradores das ocupações urbanas, foi uma resposta real para a fome. Para a organização social, se configurou como possibilidade de realizarem trabalhos comunitários estruturadores no território.

Após a vitória na sentença judicial - considerada uma surpresa por todos os sujeitos dos Grupos Focais - a Romaria da Terra seguiu às celebrações da conquista da posse. Foi um momento de debates sobre o futuro coletivo, em particular, a respeito da ocupação do território, gerando um cenário de rebuliço, tanto na festa como pelo que veio a seguir dessa. A decisão de partilharem o espaço com quem precisasse de um lugar para morar exigiu coragem e ações estratégicas visando à derrubada de cercas e acolher os recémchegados. Da resistência na posse da terra construíram uma ação organizada proativa de ocupação total do território. Os posseiros se constituíram como força social hegemônica no território, ao largo do poder público. Do improviso na acolhida aos recém-chegados, os posseiros planejaram o território como um loteamento: oitocentos e trinta e dois lotes, trinta e seis quadras, cinco ruas e vários espaços comunitários.

Desde então, o habitante da Vila União dos Operários não é mais posseiro, é proprietário do seu lote. Um lote instalado formalmente em um espaço urbano que dispõe de serviços e equipamentos públicos necessários à vida cidadã. As vidas dos moradores estiveram condicionadas a decisões políticas definidas desde fora do âmbito local, muitas vezes tratadas como caso de polícia, o que Ihes limitava o protagonismo, sem, no entanto, prejudicar a luta por assumir um movimento social que, para além da posse de um lote de terra, Ihes trouxe um sentido político e ético para sua existência.

O trabalho de memória realizado nos grupos focais permitiu não apenas uma descrição mais afetiva do processo histórico de conquista e desenvolvimento habitacional da 
Vila União dos Operários, mas a compreensão de como os protagonistas do processo dispõem, no presente, sobre o que viveram e construíram conjuntamente. Tal trabalho de memória confirma, é claro, a hipótese de pesquisa: as lutas pela terra e pelas condições de habitabilidade povoam abundantemente a memória coletiva dos entrevistados.

\section{Considerações finais}

Por meio de diferentes perspectivas, em particular os depoimentos obtidos por meio de grupos focais, este trabalho apresentou o processo histórico do movimento social de luta pelo acesso à moradia e por melhores condições de habitabilidade ocorrido na cidade de Canoas/RS entre 1980 e 2014. Esse processo histórico tem uma importância destacada, pois, conforme os próprios posseiros à época, foi uma "surpresa" a obtenção legal da posse da terra. Além disso, a comunidade da Vila União dos Operários seguiu protagonizando práticas ímpares em seus usos do território urbano, contando com a partilha coletiva da terra, redes de solidariedade para construção de moradias e equipamentos comuns e envolvimento afetivo em torno da fé.

Os resultados discutidos aqui podem ser considerados parciais. Isso por duas razões: primeiro, porque o Grupo de Pesquisa Memória, Cultura e Identidade (CNPq) segue produzindo estudos sobre a História Social e Urbana de Canoas/RS, assim como pesquisas nas áreas de Antropologia e Sociologia Urbanas. A segunda razão é a de que a pesquisa com os grupos focais gerou uma massa significativa de dados e informações que serão objeto de novas publicações.

\section{Referências:}

BARBOUR, Rosaline. Grupos Focais. Tradução de Marcelo Figueiredo Duarte, Porto Alegre, Artmed, 2009.

BETTO, Frei. Catecismo Popular, São Paulo, Ática, 1991.

BRUM, Argemiro J. o Desenvolvimento Econômico Brasileiro Vozes, Petrópolis, 1982.

CANDAU, Joël. Memória e identidade. São Paulo: Contexto, 2011.

FARIA, Otavio Augusto de. Diccionario Geográphico Histórico e Estatístico do Estado do Rio Grande do Sul. Porto Alegre: Ed. Globo, 1914, p. 8.

FARIAS, F. R.; PINTO, D. S. Memória social e situação traumática. Morpheus (UNIRIO. Online), v. 9, p. 177-202, 2016. 
FIOROTTI, Ivo. A Irrupção do novo nos Clubes de Mães. 1987, 82 p. Trabalho de Conclusão de Curso (Graduação em Teologia). Pontifícia Universidade Católica do Rio Grande do Sul, Porto Alegre.

FOLLMANN, José Ivo; PINHEIRO, ADEVANIR APARECIDA. Afrodescendentes em São Leopoldo: memória coletiva e processos de identidade. Ciências Sociais Unisinos, São Leopoldo, Vol. 47, N. 2, p. 141-152, mai/ago 2011. Disponível em: <http://revistas.unisinos.br/index.php/cienciassociais/article/view/csu.2011.47.2.05>. Acesso em: 17 fev. 2015.

FUNDAÇÃO DE ECONOMIA E ESTATÍSTICA. De Província de São Pedro a Estado do Rio Grande do Sul - censos do RS (1803-1950). Porto Alegre, 1981.

GENSBURGER, Sarah; LEFRANC, Sandrine. À quoi servente les politiques de mémoire. Paris: Presses de SciencesPo., 2017.

GOHN, Maria da Glória. História dos movimentos e lutas sociais - a construção da cidadania dos brasileiros. São Paulo, Edições Loyola, 1995.

Movimentos sociais e lutas pela moradia. São Paulo, Edições Loyola, 1991.

O protagonismo da sociedade civil: movimentos sociais, ONGs e redes solidárias. São Paulo, Cortez, 2005.

Os sem-terra, ONGs e cidadania. 3 ed. São Paulo, Cortez, 2003.

contemporâneos. São Paulo Edições Loyola, 1997.

GONDAR, J. Cinco proposições sobre memória social. In: DOBEDEI, V.; FARIAS, F. R. de; GONDAR, J. (Eds.). Por que memória social? Revista Morpheus, v. 9, n. 15, p. 19-40, 2016.

GUI, Roque Tadeu. Grupo focal em pesquisa qualitativa aplicada: intersubjetividade e construção de sentido. Rev. Psicol., Organ. Trab., Jun. 2003, vol.3, no 1, p.135-159. Disponível em: <https://periodicos.ufsc.br/index.php/rpot/article/ view/7071>. Acesso em: 15 fev. 2015

HALBWACHS, Maurice. A memória individual e memória coletiva. In: A memória coletiva. Trad. por Laís T. Benoir. São Paulo: Centauro, 2006. pp. 29-142.

HISTÓRIA de nossos prefeitos. José João de Medeiros. Canoas: Prefeitura Municipal de Canoas, 2005. (Série Documento, 6)

Documento, 4)

Sady Fontoura Schivitz. Canoas: Prefeitura Municipal de Canoas, 2003. (Série

Sezefredo Azambuja Vieira. Canoas: Prefeitura Municipal de Canoas, 2004. (Série Documento, 5) 
JORGE, Jairo. Radicalizar a Democracia. Porto Alegre, Tomo Editoria, 2014.

MACHADO, Odilon Kieling. As CEBs no Rio grande do Sul: O caso do bairro Mathias Velho - Município de Canoas (1975-1988). 2012, 222f. Dissertação (Mestrado em História). Programa de Pós-Graduação em História, Universidade Federal de Santa Maria, Santa Maria, 2012.

MARKOVA, Ivana. Les focus groups, In: MOSCOVIVICI, Serge \& BUSCHINI, Fabrice. Les méthodes des sciences humaines. Paris, Press Universitaires de France, 2003, pp. 221242.

MINAYO, Maria Cecília de Souza (org.). Pesquisa social: teoria, método e criatividade. $32^{a}$ ed. Petrópolis, Vozes, 2012.

PENNA, Rejane (Coord.). Canoas - para lembrar quem somos: Mathias Velho. Canoas, Gráfica Editora La Salle, 2000.

PEREIRA, Odvaldo Nascimento. Vida do Migrante (11/12/1980). In: Poesia Popular. Anexo do Boletim da gente, $n^{\circ}$ 13, Janeiro/Fevereiro. CEDIV-Centro de Documentação da Igreja de

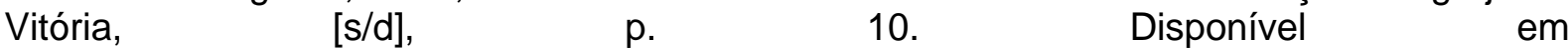
<http://www.cpvsp.org.br/upload/periodicos/pdf/PPOEPES010000005.pdf>. Acesso em 12 de agosto de 2017.

POLLACK, Michael. Memória e identidade social. Estudos Históricos, v.5 n. 10, 1992, p. 200-212. Disponível em: <http://bibliotecadigital.fgv.br/ojs/index.php/ reh/ article/view/1941/0>. Acesso em: 15 fev. 2015.

QUADRO das Romarias da Terra Rio Grande do Sul. Disponível em <http://www.arquidiocesedepassofundo.com.br/site/download/romaria_da_terra/Quadro_Ro marias_da_Terra_RS.pdf >. Acesso em 12 de setembro de 2017.

SADER, Eder. Quando novos personagens entram em cena - Experiências e Lutas dos Trabalhadores na Grande São Paulo. Rio de Janeiro, Paz e Terra, 1988.

SCHERER-WARREN, Ilse\& KRISCHKE, Paulo J. (org.). Uma revolução no cotidiano? Os novos movimentos sociais na América Latina. São Paulo, Editora Brasiliense, 1989.

SCHERER-WARREN, Ilse. Movimentos sociais; um ensaio de interpretação sociológica. Florianópolis, Editora da UFSC, 1987.

VIEGAS, Danielle Heberle. Entre o(s) passado(s) e o(s) futuro(s) da cidade: um estudo sobre a urbanização de Canoas/RS (1929-1959). 2011, 186f. Dissertação (Mestrado em História). Pontifícia Universidade Católica do Rio Grande do Sul, Porto Alegre, 2011. Disponível em: <http://tardis.pucrs.br/dspace/bitstream/10923/ 3965/ 1/ 000430524Texto\%2BCompleto -0.pdf>. Acesso em: 12 mai. 2014.

WEBER, Regina. A região metropolitana e as "cidades-operárias". In: GRIJÓ, Luiz Alberto et al. (Orgs.) Capítulos de História do Rio Grande do Sul. Porto Alegre: Ed. da UFRGS, p. 309-393. 


\section{ENTREVISTAS:}

ALVES, Jandira; GONÇALVES, Dejair; LOPES, Juvila Cassol; OLIVEIRA, Adegildo de; OLIVEIRA, Judite de; SILVA, Eva Reis da; SILVA, Maria Gessi Lopes da; VIEIRA, Maria Adélia da Rosa. Entrevista Grupo Focal 1. Canoas, 01 de julho de 2014.

BELLEBONI, Saulo; DORNELES, Luciane Mazurik; FIOROTTI, Ivonete Maria de Almeida; MACHADO, Paula Regina Pereira; SEVERO, Roseline dos Santos; SILVA, Jair; TEIXEIRA, João Delci. Entrevista Grupo Focal 3. Canoas, 10 de janeiro de 2015.

CARISSIMI, Iracema; CONCEIÇÂO, José Antônio da (Juca); CONCEIÇÂO, Lair Silva; MICHEL, Aluízio; OLIVEIRA, Lucy Dalva Lopes da; PEREIRA, Edelmiro Aires; ROSA, Nildo Natal Barbosa. Entrevista Grupo Focal 2. Canoas, 26 de agosto de 2014.

\section{FONTES DOCUMENTAIS:}

PREFEITURA Municipal de Canoas. Lei № 1.662 de 5 de novembro de 1975. Disponível em https://leismunicipais.com.br/a1/rs/c/canoas/lei-ordinaria/1975/167/1662/lei-ordinaria-n-16621975-da-as-atuais-vilas-existentes-na-sede-do-municipio-a-denominacao-de-bairro-edetermina-outras-providencias?q=5\%20de\%20novembro\%20de\%201975. Acesso em 20 de maio de 2017.

TRIBUNAL de Alçada. Acórdão n. 100287119, 18 de novembro de 1983. Disponível em https://view.officeapps.live.com/op/view.aspx?src=http://www.prr4.mpf.gov.br/pesquisaPaulo Leivas/arquivos/acao moradia.doc. Acesso em 20 de maio de 2017.

BRASIL. Lei Complementar Federal 14 de 08/06/1973,Estabelece as regiões metropolitanas de São Paulo, Belo Horizonte, Porto Alegre, Recife, Salvador, Curitiba, Belém e Fortaleza. Disponível em <http://www2.camara.leg.br/legin/fed/leicom/1970-1979/leicomplementar-148-junho-1973-367020-norma-pl.html>. Acesso em 20 de maio de 2017. 